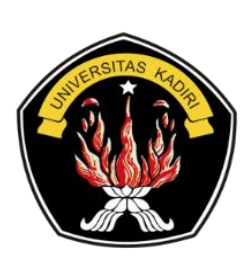

Tersedia secara online di http://ojs.unik-kediri.ac.id/index.php/jatiunik/issue/view/76

\title{
Analytic Hierarchy Process (AHP) dan Fuzzy TOPSIS pada Pemilihan Himpunan Pairing Terpilih dari Jadwal Penerbangan
}

\author{
Dinita Rahmalia*1, Awawin Mustana Rohmah ${ }^{2}$, Nuril Lutvi Azizah ${ }^{3}$ \\ ${ }^{1,2}$ Program Studi Matematika, Fakultas MIPA, Universitas Islam Darul Ulum Lamongan, Jln. Airlangga 3 Sukodadi \\ Lamongan \\ ${ }^{3}$ Program Studi Teknik Informatika, Fakultas Teknik, Universitas Muhammadiyah Sidoarjo \\ Email : dinitarahmalia@gmail.com
}

\begin{tabular}{|c|c|}
\hline Informasi Artikel & Abstract \\
\hline $\begin{array}{l}\text { Riwayat Artikel : } \\
\text { Received : } 7 \text { - Juli }-2020 \\
\text { Revised }: 7 \text { - Oktober - } 2020 \\
\text { Accepted : } 9 \text { - Oktober }-2020\end{array}$ & $\begin{array}{l}\text { In the flight industry, there are two highest costs such as fuel } \\
\text { cost and crew cost. The crew cost is affected by pairings selected } \\
\text { from flight schedule. This research will explain about selecting } \\
\text { the set of selected pairings using Analytic Hierarchy Process } \\
\text { (AHP) and Fuzzy Technique for Order Performance by } \\
\text { Similarity to Ideal Solution (Fuzzy TOPSIS). Before using either }\end{array}$ \\
\hline $\begin{array}{l}\text { Kata kunci : } \\
\text { Algoritma Greedy } \\
\text { Analytic Hierarchy Process } \\
\text { Decision-making } \\
\text { Fuzzy TOPSIS } \\
\text { Scheduling Problems }\end{array}$ & $\begin{array}{l}\text { set of selected pairings using greedy algorithm. After collection } \\
\text { of the set of selected pairings is formed, then we determine goal } \\
\text { and criteria. The goal is selecting the set of selected pairings } \\
\text { from some alternatives. For each the set of selected pairings, } \\
\text { there are some criterions such as the number of deadhead, the } \\
\text { number of pairing A2, the number of pairing A3, the number of } \\
\text { pairing A4, the number of pairing A5, and the number of pairing } \\
\text { A6. Based on simulation results, both AHP and Fuzzy TOPSIS } \\
\text { can select and give the rank of priority in entire the set of } \\
\text { selected pairings. }\end{array}$ \\
\hline
\end{tabular}

\section{A b s t rak}

Pada industri maskapai penerbangan, terdapat dua biaya yang sangat besar yaitu biaya bahan bakar dan biaya kru. Biaya kru dipengaruhi oleh pairing yang terpilih dari jadwal penerbangan. Pada penelitian ini akan dilakukan pemilihan himpunan pairing terpilih menggunakan metode Analytic Hierarchy Process (AHP) dan Fuzzy Technique for Order Performance by Similarity to Ideal Solution (Fuzzy TOPSIS). Sebelum menggunakan AHP atau Fuzzy TOPSIS, akan dibentuk kumpulan dari himpunan pairing terpilih menggunakan greedy algorithm. Setelah kumpulan himpunan pairing terpilih terbentuk, maka dibentuk goal dan kriteria. Goal adalah memilih himpunan pairing terpilih dari beberapa alternative. Pada setiap himpunan pairing yang terpilih, terdapat beberapa kriteria seperti jumlah deadhead, jumlah pairing A2, jumlah pairing A3, jumlah pairing A4, jumlah pairing A5, dan jumlah pairing A6. Berdasarkan hasil perhitungan, metode AHP dan Fuzzy TOPSIS 
dapat memilih dan memberi peringkat prioritas pada pemilihan himpunan pairing terpilih.

\section{Pendahuluan}

Indonesia merupakan negara yang luas dan juga memiliki ribuan pulau sehingga transportasi udara seperti pesawat sangat diminati oleh masyarakat. Pada industri maskapai penerbangan, terdapat dua biaya yang sangat besar yaitu biaya bahan bakar dan biaya kru. Biaya kru dipengaruhi oleh pairing yang terpilih dari jadwal penerbangan. Pairing adalah serangkaian penerbangan yang dijalankan oleh satu kelompok kru yang dimulai dari suatu bandara pada penerbangan pertama hingga ke bandara yang sama pada penerbangan terakhir. Setiap pairing dikendalikan oleh satu kelompok kru. Jadi kru tersebut berangkat dan sampai di bandara yang sama (homebase) dalam menjalankan tugasnya [1].

Linear integer programming merupakan masalah yang sering ditemukan pada optimisasi. Terdapat beberapa aplikasi pada linear integer programming seperti optimisasi perencanaan produksi [2], [3] dan masalah transportasi [4]. Pemilihan pairing optimal merupakan salah satu dari masalah pada linear integer programming dengan kendala. Kendala yang digunakan adalah setiap nomor penerbangan harus ter-cover minimum satu pairing. Solusi dari pemilihan pairing optimal merupakan bilangan biner sehingga disebut binary programming [5]-[7].

AHP dan Fuzzy TOPSIS dapat digunakan dalam menyelesaikan pengambilan keputusan dengan banyak kriteria [8]-[10]. Pada penelitian ini akan dilakukan pemilihan himpunan pairing terpilih menggunakan metode Analytic Hierarchy Process (AHP) [11] dan Fuzzy Technique for Order Performance by Similarity to Ideal Solution (Fuzzy TOPSIS). AHP membutuhkan pembuat keputusan untuk menilai tentang tingkat kepentingan dari masing-masing kriteria dan menentukan preference untuk masing-masing alternative yang menggunakan kriteria tersebut [6], [12]. Sedangkan Fuzzy TOPSIS berdasarkan konsep bahwa alternative yang terpilih memiliki jarak terpendek ke Positive Ideal Solution (PIS) dan jarak terjauh ke Negative Ideal Solution (NIS) [13]-[15]. Pada penelitian sebelumnya, metode AHP telah digunakan pada pemilihan mobil dengan mempertimbangkan kriteria harga, jarak tempuh, kenyamanan, dan model [13], [15], [16], evaluasi website. Metode Fuzzy TOPSIS juga telah digunakan pada menetukan tingkat kepuasan layanan penerimaan siswa baru [14].

Metode Fuzzy TOPSIS merupakan pengembangan dari himpunan Fuzzy [5], [17]. Perbedaan antara himpunan Fuzzy dengan himpunan crisp adalah dimana himpunan fuzzy memiliki fungsi keanggotaan sedangkan himpunan crisp tidak memiliki. Terdapat banyak aplikasi Fuzzy yaitu Fuzzy Clustering Means untuk mengelompokkan data [18]. ANFIS untuk peramalan cuaca. Selain itu fuzzy juga sering digunakan pada masalah optimisasi dan kontrol.

Pada penelitian ini akan dilakukan pemilihan himpunan pairing terpilih beserta peringkat prioritas. Sebelum menggunakan AHP atau Fuzzy TOPSIS, akan dibentuk kumpulan dari himpunan pairing terpilih menggunakan greedy algorithm. Greedy algorithm digunakan karena dapat memenuhi kendala solusi biner dan setiap nomor penerbangan akan ter-cover minimal satu pairing [16], [19].Setelah kumpulan himpunan pairing terpilih terbentuk, maka dibentuk goal dan kriteria. Goal adalah memilih himpunan pairing terpilih 
dari beberapa alternative. Pada setiap himpunan pairing terpilih, terdapat beberapa kriteria seperti jumlah deadhead, jumlah pairing $\mathrm{A}^{2}$, jumlah pairing $\mathrm{A}^{3}$, jumlah pairing $\mathrm{A}^{4}$, jumlah pairing $\mathrm{A}^{5}$, dan jumlah pairing $\mathrm{A}^{6}$. MP

Berdasarkan hasil perhitungan, metode AHP dan Fuzzy TOPSIS dapat memilih dan memberi peringkat prioritas pada pemilihan himpunan pairing terpilih.

\section{Tinjauan Pustaka}

Pada bagian ini akan dijelaskan tentang pengertian pairing dan deadhead, model matematika pemilihan pairing optimal, dan pembentukan kumpulan dari himpunan pairing terpilih.

\subsection{Pairing dan Deadhead}

Pairing adalah serangkaian penerbangan yang dijalankan oleh satu kelompok kru yang dimulai dari suatu bandara pada penerbangan pertama hingga ke bandara yang sama pada penerbangan terakhir. Setiap pairing dikendalikan oleh satu kelompok kru. Jadi kru tersebut berangkat dan sampai di bandara yang sama (homebase) dalam menjalankan tugasnya. Contoh pairing dapat dilihat pada Gambar 1. Pada Gambar 1 terlihat bahwa nomor penerbangan 1 terbang dari bandara A menuju bandara $\mathrm{B}$, kemudian melakukan transit, dan seterusnya sampai nomor penerbangan 4 terbang dari bandara D kembali ke bandara A. Dalam hal ini, bandara A disebut homebase [20].

\begin{tabular}{|c|c|c|c|c|c|c|c|c|}
\hline $\begin{array}{c}\text { Pre } \\
\text { Journey } \\
(90 \mathrm{mnt})\end{array}$ & $\begin{array}{c}\text { Flight 1 } \\
(\mathrm{A} \rightarrow \mathrm{B})\end{array}$ & $\begin{array}{c}\text { Transit } \\
\text { Time } \\
(\pi)\end{array}$ & $\begin{array}{c}\text { Flight 2 } \\
(\mathrm{B} \rightarrow \mathrm{C})\end{array}$ & $\begin{array}{c}\text { Transit } \\
\text { Time } \\
(\pi)\end{array}$ & $\begin{array}{c}\text { Flight 3 } \\
(\mathrm{C} \rightarrow \mathrm{D})\end{array}$ & $\begin{array}{c}\text { Transit } \\
\text { Time } \\
(\pi)\end{array}$ & $\begin{array}{c}\text { Flight 4 } \\
(\mathrm{D} \rightarrow \mathrm{A})\end{array}$ & $\begin{array}{c}\text { Post } \\
\text { Journey } \\
(90 \mathrm{mnt})\end{array}$ \\
\hline
\end{tabular}

Gambar 1. Contoh Pairing Penerbangan

Cara membentuk pairing adalah menggunakan matriks possibility $A^{n}, n=2,3,4,5,6$. Matriks possibility $A^{n}$ menyimpan pairing yang terbentuk dari $n$ nomor penerbangan sehingga setiap kolom pada matriks possibility $A^{n}$ memiliki $n$ elemen yang bernilai 1 . Pairing $A^{n}$ berisi $n$ nomor penerbangan.

Dalam pemilihan pairing, terdapat kasus nomor penerbangan bersifat deadhead. Deadhead adalah kasus dimana terdapat nomor penerbangan yang sama dalam pairing yang berbeda. Hal ini mengakibatkan satu kelompok kru ditransfer ke bandara tujuan dengan penerbangan yang lain pada pairing yang berbeda [21].

\subsection{Model Matematika Pemilihan Pairing Optimal}

Masalah pemilihan pairing diselesaikan dengan cara menentukan himpunan possible pairing dari setiap nomor penerbangan. Setelah himpunan possible pairing terbentuk, akan dibentuk himpunan pairing optimal yang meminimumkan biaya operasional (biaya pairing dan biaya deadhead) dengan kendala semua nomor penerbangan termuat oleh minimal satu pairing.

Model matematika pemilihan pairing adalah sebagai berikut [22] : 


$$
\min \sum_{k=1}^{N_{P}} c_{k} x_{k}+\sum_{i=1}^{N_{F}} d_{i}\left(\sum_{k=1}^{N_{P}} a_{i k} x_{k}-1\right)
$$

dengan kendala :

$$
\begin{gathered}
\sum_{k=1}^{N_{P}} a_{i k} x_{k} \geq 1, \quad i=1,2, \ldots, N_{F} \\
x_{k} \in\{0,1\}, \quad k=1,2, \ldots, N_{P}
\end{gathered}
$$

Keterangan dari model di atas adalah sebagai berikut :

$N_{P}$ : Jumlah possible pairing

$N_{F}$ : Jumlah nomor penerbangan

$c_{k}$ : Biaya pairing $k$

$d_{i}$ : Biaya deadhead nomor penerbangan $i$

$$
a_{i k}=\left\{\begin{array}{l}
1, \quad \text { jika nomor penerbangan i termuat dalam pairing } \mathrm{k} \\
0, \quad \text { jika nomor penerbangan i tidak termuat dalam pairing } \mathrm{k}
\end{array}\right.
$$

Dengan variabel keputusan adalah :

$$
x_{k}=\left\{\begin{array}{lr}
1, & \text { jika pairing k terpilih } \\
0, & \text { jika pairing k tidak terpilih }
\end{array}\right.
$$

\subsection{Pembentukan Kumpulan dari Himpunan Pairing Terpilih}

Pembentukan himpunan pairing terpilih dapat dilakukan dengan membangkitkan himpunan possible pairing dari setiap nomor penerbangan. Setelah himpunan dari possible pairing terbentuk, akan dipilih himpunan pairing yang memenuhi kendala yaitu setiap nomor penerbangan ter-cover minimal satu pairing. Himpunan pairing terpilih dinyatakan dengan biner yaitu 0 jika pairing tidak terpilih dan 1 jika pairing terpilih.

Sebelum menggunakan AHP atau Fuzzy TOPSIS, akan dibentuk kumpulan dari himpunan pairing terpilih pada persamaan (4) menggunakan greedy algorithm. Greedy algorithm digunakan karena dapat memenuhi kendala solusi biner dan setiap nomor penerbangan akan ter-cover minimal satu pairing.

Algoritma untuk membentuk kumpulan sebanyak $M$ dari himpunan pairing terpilih adalah sebagai berikut [23] :

For $j=1: M$

1. Misalkan $U$ adalah nomor penerbangan yang belum ter-cover, $S_{i}, i=1,2, \ldots, N_{F}$ adalah pairing yang mengkover nomor penerbangan $i, w_{i}, i=1,2, \ldots, N_{F}$ adalah jumlah pairing yang mengkover nomor penerbangan $i$, dan $x_{k}=0, k=1,2, \ldots, N_{P}$ adalah solusi variabel keputusan yaitu himpunan pairing yang terpilih.

2. Tetapkan $U=F, S_{i}=\{\}, w_{i}=0$ untuk setiap $i=1,2, \ldots, N_{F}, x_{k}=0$ untuk setiap $k=1,2, \ldots, N_{P}$ 
For $i=1: N_{F}$

$$
\text { If }\left(w_{i}=0\right)
$$

a. Tentukan $P_{i}$ : himpunan pairing yang meng-cover nomor penerbangan $i$

b. Pilih pairing $q \in P_{i}$ secara acak

c. Tentukan $F_{q}$ : himpunan nomor penerbangan yang ter-cover oleh pairing $q \in P_{i}$

d. Update $S_{i} \leftarrow S_{i} \cup q, w_{i} \leftarrow w_{i}+1$ untuk $i \in F_{q}$

e. Update $U \leftarrow U-F_{q}, x_{q}=1$

End

End

End

Setelah kumpulan sebanyak $M$ dari himpunan pairing terpilih terbentuk, maka akan dikembangkan grafik seperti Gambar 2 dari masalah pemilihan himpunan pairing terpilih yaitu goal dan kriteria. Goal adalah memilih himpunan pairing terpilih dari $M$ alternative. Pada setiap himpunan pairing terpilih, terdapat beberapa kriteria seperti jumlah deadhead, jumlah pairing $A^{2}$, jumlah pairing $A^{3}$, jumlah pairing $A^{4}$, jumlah pairing $A^{5}$, dan jumlah pairing $\mathrm{A}^{6}$ yang akan dianalisa seperti Gambar 2. Karena model matematika pemilihan pairing adalah masalah minimalisasi, maka pada masing-masing kriteria, semakin kecil nilainya, maka akan semakin tinggi tingkat kepentingannya (prioritas).

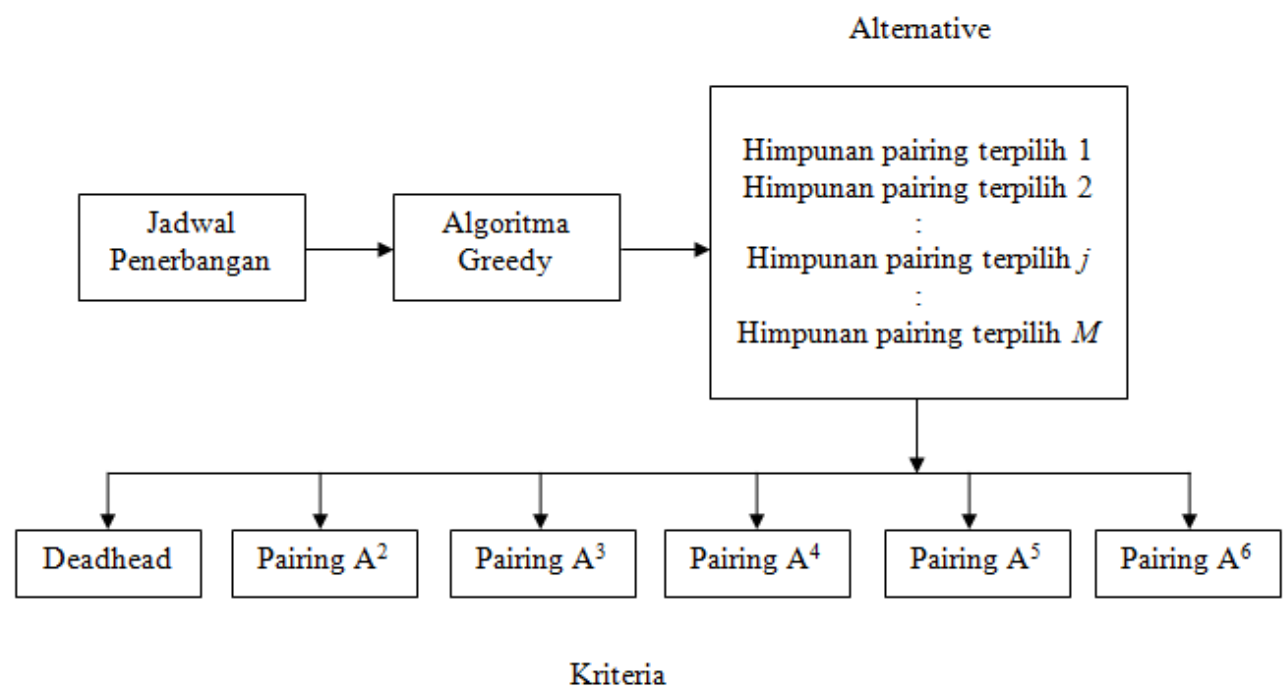

Gambar 2. Alternative dan Kriteria pada Pemilihan Himpunan Terpilih

\section{Metode Penelitian}

Metode yang digunakan dalam pemilihan himpunan pairing terpilih adalah menggunakan Analytic Hierarchy Process (AHP) dan Fuzzy Technique for Order Performance by Similarity to Ideal Solution (Fuzzy TOPSIS). AHP membutuhkan pembuat keputusan untuk menilai tentang tingkat kepentingan dari masing-masing kriteria dan 
menentukan preference untuk masing-masing alternative yang menggunakan kriteria tersebut. Sedangkan Fuzzy TOPSIS berdasarkan konsep bahwa alternative yang terpilih memiliki jarak terpendek ke Positive Ideal Solution (PIS) dan jarak terjauh ke Negative Ideal Solution (NIS).

\subsection{Fuzzy Number}

Fuzzy number (FN) adalah himpunan fuzzy di $R$, dengan pemetaan $x: R \rightarrow[0,1]$.

Pada penelitian ini, FN menggunakan fungsi keanggotaan segitiga (triangular). FN dengan fungsi keanggotaan segitiga (triangular) didefinisikan sebagai berikut [3]:

$$
x(t)=\left\{\begin{array}{cc}
0 & \text { jika } t<a \\
\frac{t-a}{b-a} & \text { jika } a \leq t<b \\
\frac{c-t}{c-b} & \text { jika } b \leq t<c \\
0 & t>c
\end{array}\right.
$$

Dengan nilai $a \leq b \leq c$ dapat dapat dinotasikan sebagai $\tilde{x}=(a, b, c)$

\subsection{Analytic Hierarchy Process (AHP)}

Analytic Hierarchy Process (AHP) dikembangkan oleh Thomas L. Saaty untuk menyelesaikan masalah pengambilan keputusan dengan banyak kriteria (multicriteria). AHP membutuhkan pembuat keputusan untuk menilai tentang tingkat kepentingan dari masing-masing kriteria dan menentukan preference untuk masing-masing alternative yang menggunakan kriteria tersebut. Output dari AHP adalah peringkat prioritas dari alternative berdasarkan keseluruhan preference yang ditentukan oleh pembuat keputusan. Tabel 1 adalah skala perbandingan untuk tingkat kepentingan yang digunakan pada AHP [24].

Tabel 1. Skala Perbandingan untuk Tingkat Kepentingan

\begin{tabular}{lc}
\hline \multicolumn{1}{c}{ Penilaian } & Rating Numerik $c$ \\
\hline Sangat penting & 6 \\
& 5 \\
Penting & 4 \\
& 3 \\
Cukup Penting & 2 \\
Sama Penting & 1 \\
\hline
\end{tabular}

Langkah-langkah AHP untuk menentukan keseluruhan prioritas dari alternative adalah sebagai berikut [25] :

1. Konstruksi matriks perbandingan pasangan (pairwise comparison matrix) dengan elemen $p_{i j}$ adalah :

$$
p_{i j}=1 \mathrm{jika} i=j
$$




$$
p_{i j}= \begin{cases}c & \text { jika kriteria i lebih penting daripada kriteria } \mathrm{j} \\ \frac{1}{c} & \text { jika kriteria } \mathrm{j} \text { lebih penting daripada kriteria } \mathrm{i}\end{cases}
$$

2. Jumlahkan nilai di setiap kolom matriks perbandingan pasangan.

3. Bagi setiap elemen pada matriks perbandingan pasangan dengan jumlah nilai setiap kolom sehingga menghasilkan matriks perbandingan pasangan dalam bentuk normal (normalized pairwise comparison matrix).

4. Hitung $z_{i}$ yaitu rata-rata elemen pada setiap baris matriks perbandingan pasangan dalam bentuk normal. Hasil perhitungan rata-rata adalah prioritas untuk kriteria. Semakin tinggi nilainya menandakan tingkat kepentingan yang semakin tinggi, dan sebaliknya.

5. Untuk setiap kriteria, lakukan langkah 1-4 untuk membandingkan setiap alternative sehingga menghasilkan $r_{i j}$ yaitu rating kriteria $i$ terhadap alternative $j$

6. Tentukan keseluruhan prioritas untuk setiap alternative menggunakan persamaan (8). Semakin tinggi nilainya menandakan tingkat kepentingan yang semakin tinggi, dan sebaliknya.

$$
Q_{j}=\sum_{i} z_{i} r_{i j}
$$

\subsection{Fuzzy TOPSIS}

Technique for Order Performance by Similarity to Ideal Solution (TOPSIS) ditemukan oleh Hwang dan Yoon dan merupakan teknik untuk menyelesaikan masalah Multi Criteria Decision Making (MCDM). Metode ini berdasarkan konsep bahwa alternative yang terpilih memiliki jarak terpendek ke Positive Ideal Solution (PIS) (solusi yang meminimumkan cost criteria dan memaksimumkan benefit criteria) dan jarak terjauh ke Negative Ideal Solution (NIS).

Masalah pada Fuzzy MCDM dengan $m$ alternative $\left\{A_{1}, A_{2}, \ldots, A_{m}\right\}$ dihubungkan dengan $n$ kriteria $\left\{C_{1}, C_{2}, \ldots, C_{n}\right\}$ dapat ditulis dalam bentuk matriks pada persamaan (9) [15]

$$
\tilde{X}=\left[\begin{array}{cccc}
\tilde{x}_{11} & \tilde{x}_{12} & \ldots & \tilde{x}_{1 n} \\
\tilde{x}_{21} & \tilde{x}_{22} & \ldots & \tilde{x}_{2 n} \\
\ldots & \ldots & \ldots & \ldots \\
\tilde{x}_{m 1} & \tilde{x}_{m 2} & \ldots & \tilde{x}_{m n}
\end{array}\right]
$$

dimana $\tilde{x}_{i j}$ adalah nilai fuzzy (triangular FN, trapeziodal FN, dan sebagainya) yang merepresentasikan nilai alternative ke-i terhadap kriteria j.

Bobot tingkat kepentingan dari kriteria adalah :

$$
\tilde{W}=\left(\tilde{w}_{1}, \tilde{w}_{2}, \ldots, \tilde{w}_{n}\right)
$$


Jika $\tilde{x}=\left(a_{1}, b_{1}, c_{1}\right), \tilde{y}=\left(a_{2}, b_{2}, c_{2}\right)$ adalah dua FN dengan fungsi keanggotaan segitiga (triangular) maka jarak antara dua segitiga FN adalah :

$$
d(\tilde{x}, \tilde{y})=\sqrt{\frac{1}{3}\left[\left(a_{1}-a_{2}\right)^{2}+\left(b_{1}-b_{2}\right)^{2}+\left(c_{1}-c_{2}\right)^{2}\right]}
$$

Algoritma Fuzzy TOPSIS adalah sebagai berikut [14]:

1. Tentukan rating pada kriteria dan alternative

Misalkan terdapat kelompok pembuat keputusan dengan jumlah $K$ anggota. Rating fuzzy dari pembuat keputusan $k$ tentang alternative $A_{i}$ terhadap kriteria $C_{j}$ dinotasikan dengan $\tilde{x}_{i j}=\left(a_{i j}^{k}, b_{i j}^{k}, c_{i j}^{k}\right)$ dan bobot dari kriteria $C_{j}$ dinotasikan dengan $\tilde{w}_{j}=\left(w_{j 1}^{k}, w_{j 2}^{k}, w_{j 3}^{k}\right)$

2. Hitung rating fuzzy agregat untuk alternative dan bobot fuzzy agregat untuk kriteria. Rating fuzzy agregat $\tilde{x}_{i j}=\left(a_{i j}^{k}, b_{i j}^{k}, c_{i j}^{k}\right)$ dari alternative $i$ terhadap kriteria $j$ adalah :

$$
a_{i j}=\min _{k}\left\{a_{i j}^{k}\right\}, b_{i j}=\frac{1}{K} \sum_{k=1}^{K} b_{i j}^{k}, c_{i j}=\max _{k}\left\{c_{i j}^{k}\right\}
$$

Bobot $f u z z y$ agregat $\tilde{w}_{j}=\left(w_{j 1}^{k}, w_{j 2}^{k}, w_{j 3}^{k}\right)$ untuk kriteria $C_{j}$ adalah sebagai berikut :

$$
w_{j 1}=\min _{k}\left\{w_{j 1}^{k}\right\}, w_{j 2}=\frac{1}{K} \sum_{k=1}^{K} w_{j 2}^{k}, w_{j 3}=\max _{k}\left\{w_{j 3}^{k}\right\}
$$

3. Hitung normalized fuzzy decision matrix

Bentuk normalized fuzzy decision matrix adalah $\tilde{R}=\left[\tilde{r}_{i j}\right]$, yang dapat dihitung menggunakan persamaan (14) atau persamaan (15).

$$
\begin{gathered}
\tilde{r}_{i j}=\left(\frac{a_{i j}}{c_{j}^{+}}, \frac{b_{i j}}{c_{j}^{+}}, \frac{c_{i j}}{c_{j}^{+}}\right) \text {dan } c_{j}^{+}=\max _{i}\left\{c_{i j}\right\} \text { (benefit criteria) } \\
\tilde{r}_{i j}=\left(\frac{a_{j}^{-}}{c_{i j}}, \frac{a_{j}^{-}}{b_{i j}}, \frac{a_{j}^{-}}{a_{i j}}\right) \text { dan } a_{j}^{-}=\min _{i}\left\{a_{i j}\right\} \text { (cost criteria) }
\end{gathered}
$$

4. Hitung weighted normalized fuzzy decision matrix $\tilde{V}=\left(\tilde{v}_{i j}\right)$

$$
\tilde{v}_{i j}=\tilde{r}_{i j} \times \tilde{w}_{j}
$$

5. Hitung Fuzzy Positive Ideal Solution (FPIS) $A^{+}$pada persamaan (17) dan Fuzzy Negative Ideal Solution (FNIS) $A^{-}$pada persamaan (18) 


$$
\begin{aligned}
& A^{+}=\left(\tilde{v}_{1}^{+}, \tilde{v}_{2}^{+}, \ldots, \tilde{v}_{n}^{+}\right) \text {dengan } \tilde{v}_{j}^{+}=\max _{i}\left\{v_{i j 3}\right\} \\
& A^{-}=\left(\tilde{v}_{1}^{-}, \tilde{v}_{2}^{-}, \ldots, \tilde{v}_{n}^{-}\right) \text {dengan } \tilde{v}_{j}^{-}=\min _{i}\left\{v_{i j 1}\right\}
\end{aligned}
$$

Selain itu, dapat juga menggunakan $\tilde{v}_{j}^{+}=(1,1,1)$ dan $\tilde{v}_{j}^{-}=(0,0,0)$ untuk $j=1,2, \ldots, n$

6. Hitung jarak menggunakan persamaan (11) dari setiap alternative menuju FPIS menggunakan persamaan (19) dan menuju FNIS menggunakan persamaan (20).

$$
\begin{aligned}
& d_{i}^{+}=\sum_{j=1}^{n} d\left(\tilde{v}_{i j}, \tilde{v}_{j}^{+}\right) \\
& d_{i}^{-}=\sum_{j=1}^{n} d\left(\tilde{v}_{i j}, \tilde{v}_{j}^{-}\right)
\end{aligned}
$$

7. Hitung koefisien kedekatan $C C_{i}$ untuk setiap alternative menggunakan persamaan (21).

$$
C C_{i}=\frac{d_{i}^{-}}{d_{i}^{-}+d_{i}^{+}}
$$

Susun peringkat pada alternative. Alternative dengan koefisien kedekatan tertinggi merupakan alternative yang terbaik.

\section{Hasil dan Pembahasan}

Data diperoleh dari salah satu jadwal penerbangan pesawat Boeing 738. Dari 214 nomor penerbangan, akan dibangkitkan 50 himpunan pairing terpilih yang memenuhi kendala persamaan (2) dan persamaan (3) menggunakan greedy algorithm. Setiap himpunan pairing yang terpilih, terdapat kriteria jumlah deadhead, jumlah pairing $\mathrm{A}^{2}$, jumlah pairing $\mathrm{A}^{3}$, jumlah pairing $\mathrm{A}^{4}$, jumlah pairing $\mathrm{A}^{5}$, dan jumlah pairing $\mathrm{A}^{6}$. Pemilihan himpunan pairing terpilih yang baik adalah jumlah deadhead, jumlah pairing $\mathrm{A}^{2}$ dan jumlah pairing $\mathrm{A}^{3}$ yang diperlukan adalah relative kecil karena deadhead adalah kasus dimana terdapat nomor penerbangan yang sama dalam pairing yang berbeda sedangkan jumlah pairing $\mathrm{A}^{2}$ dan jumlah pairing $\mathrm{A}^{3}$ yang diperlukan adalah relative kecil karena hanya mengkover sedikit nomor penerbangan, kemudian jumlah paring $A^{4}$, jumlah pairing $A^{5}$, dan jumlah pairing $A^{6}$ yang diperlukan adalah relative kecil karena dapat meminimumkan biaya kru. Tabel 2 memperlihatkan nilai minimum, maksimum, dan rata-rata dari 50 himpunan pairing terpilih.

Tabel 2. Karakteristik dari 50 Himpunan Pairing Terpilih

\begin{tabular}{lcccccc}
\hline & $\begin{array}{c}\text { Jumlah } \\
\text { Deadhead }\end{array}$ & $\begin{array}{c}\text { Jumlah } \\
\text { Pairing } \\
\mathrm{A}^{2}\end{array}$ & $\begin{array}{c}\text { Junlah } \\
\text { Pairing }\end{array}$ & $\begin{array}{c}\text { Jumlah } \\
\text { Pairing }\end{array}$ & $\begin{array}{c}\text { Jumlah } \\
\text { Pairing }\end{array}$ & $\begin{array}{c}\text { Jumlah } \\
\text { Pairing }\end{array}$ \\
\hline Minimum & 83 & 1 & 0 & 44 & 2 & $\mathrm{~A}^{4}$ \\
Maksimum & 142 & 7 & 6 & 62 & 8 & $\mathrm{~A}^{5}$ \\
Rata-rata & 109,26 & 4,3 & 2,86 & 52,44 & 4,84 & 12,02 \\
\hline
\end{tabular}


Karena skala nilai pada masing-masing kriteria berbeda, maka diperlukan normalisasi data sehingga setiap kriteria memiliki skala nilai antara $0-1$.

\subsection{Hasil Simulasi AHP}

Pada AHP, terlebih dahulu dirancang matriks perbandingan pasangan pada persamaan (7) dimana elemennya dapat dilihat pada Tabel 3.

Tabel 3. Elemen Matriks Perbandingan Pasangan pada AHP

\begin{tabular}{lcccccc}
\hline & Deadhead & Pairing A & Pairing A & Pairing A $^{4}$ & Pairing A & Pairing A $^{6}$ \\
\hline Deadhead & 1 & 2 & 3 & 4 & 5 & 6 \\
Pairing A $^{2}$ & 0,500 & 1 & 2 & 3 & 4 & 5 \\
Pairing A $^{3}$ & 0,333 & 0,500 & 1 & 2 & 3 & 4 \\
Pairing A $^{4}$ & 0,250 & 0,333 & 0,500 & 1 & 2 & 3 \\
Pairing A $^{5}$ & 0,200 & 0,250 & 0,333 & 0,500 & 1 & 2 \\
Pairing A $^{6}$ & 0,167 & 0,200 & 0,250 & 0,333 & 0,500 & 1 \\
\hline
\end{tabular}

Setelah simulasi AHP diterapkan, nilai keseluruhan prioritas untuk himpunan pairing terpilih sebagai alternative dapat dilihat pada Gambar 3. Semakin tinggi nilainya menandakan tingkat kepentingan yang semakin tinggi, dan sebaliknya. Berdasarkan Tabel 4 , prioritas pertama adalah himpunan pairing terpilih nomor 8 dengan nilai 0,0687 . Prioritas kedua adalah himpunan pairing terpilih nomor 26 dengan nilai 0,0408. Prioritas ketiga adalah himpunan pairing terpilih nomor 13 dengan nilai 0,0376 , dan seterusnya.

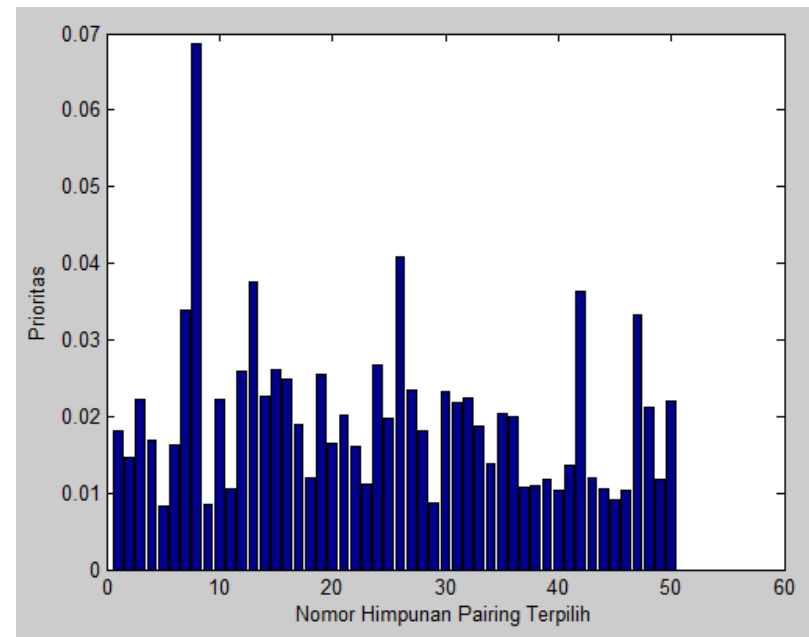

Gambar 3. Grafik Prioritas Pemilihan Himpunan Pairing Terpilih Menggunakan AHP

Tabel 4. Peringkat Terbaik Pemilihan Himpunan Pairing Terpilih Menggunakan AHP

\begin{tabular}{ccccccccc}
\hline $\begin{array}{c}\text { Pering } \\
\text { kat }\end{array}$ & $\begin{array}{c}\text { Nomor } \\
\text { Himpunan } \\
\text { Pairing } j\end{array}$ & Nilai $Q_{j}$ & $\begin{array}{c}\text { Jumlah } \\
\text { Dead } \\
\text { head }\end{array}$ & $\begin{array}{c}\text { Jumlah } \\
\text { Pairing } \\
\mathrm{A}^{2}\end{array}$ & $\begin{array}{c}\text { Jumlah } \\
\text { Pairing } \\
\mathrm{A}^{3}\end{array}$ & $\begin{array}{c}\text { Jumlah } \\
\text { Pairing } \\
\mathrm{A}^{4}\end{array}$ & $\begin{array}{c}\text { Jumlah } \\
\text { Pairing } \\
\mathrm{A}^{5}\end{array}$ & $\begin{array}{c}\text { Jumlah } \\
\text { Pairing }\end{array}$ \\
\hline 1 & 8 & 0,0687 & 83 & 1 & 3 & 53 & 4 & 9 \\
2 & 26 & 0,0408 & 92 & 2 & 2 & 52 & 2 & 13 \\
3 & 13 & 0,0376 & 96 & 4 & 0 & 57 & 4 & 9 \\
4 & 42 & 0,0363 & 91 & 6 & 1 & 47 & 6 & 12 \\
5 & 7 & 0,0338 & 90 & 7 & 2 & 48 & 4 & 12 \\
6 & 47 & 0,0332 & 92 & 6 & 2 & 45 & 6 & 13
\end{tabular}




\begin{tabular}{ccccccccc}
7 & 24 & 0,0267 & 107 & 5 & 1 & 44 & 6 & 17 \\
8 & 15 & 0,0262 & 97 & 3 & 2 & 51 & 7 & 10 \\
9 & 12 & 0,0260 & 106 & 2 & 2 & 48 & 8 & 13 \\
10 & 19 & 0,0255 & 97 & 4 & 3 & 56 & 2 & 10 \\
\hline
\end{tabular}

\subsection{Hasil Simulasi Fuzzy TOPSIS}

Fuzzy MCDM dengan 50 alternative $\left\{A_{1}, A_{2}, \ldots, A_{50}\right\}$ dihubungkan dengan 6 kriteria $\left\{C_{1}, C_{2}, \ldots, C_{6}\right\}$ yaitu jumlah deadhead, jumlah pairing $\mathrm{A}^{2}$, jumlah pairing $\mathrm{A}^{3}$, jumlah pairing $\mathrm{A}^{4}$, jumlah pairing $\mathrm{A}^{5}$ dan jumlah pairing $\mathrm{A}^{6}$. Sedangkan untuk tingkat kepentingan yaitu sangat rendah, rendah, hampir cukup, cukup, tinggi, dan sangat tinggi pada kriteria dapat dilihat pada Gambar 4. Semakin tinggi nilainya menandakan tingkat kepentingan yang semakin penting.

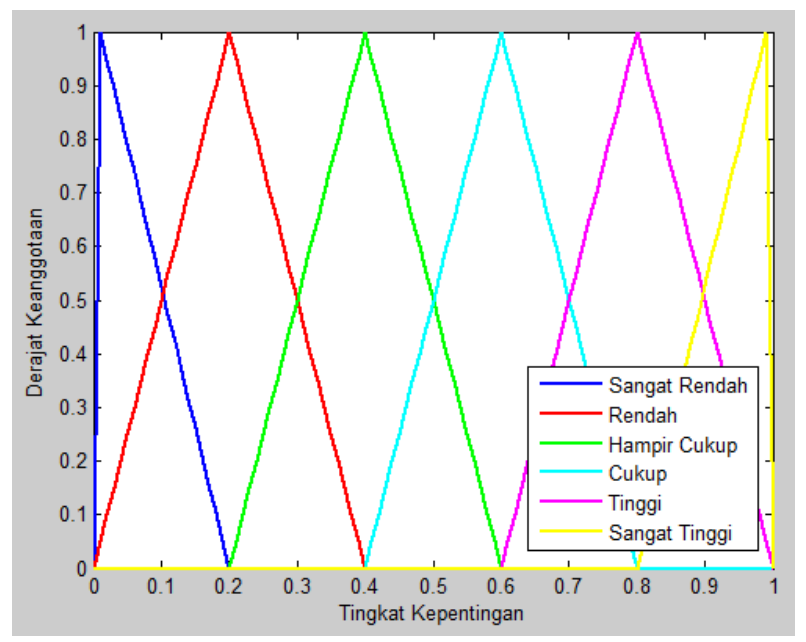

Gambar 4. Tingkat Kepentingan pada Kriteria

Setelah simulasi Fuzzy TOPSIS diterapkan, nilai keseluruhan koefisien kedekatan untuk himpunan pairing terpilih sebagai alternative dapat dilihat pada Gambar 5. Semakin tinggi nilainya menandakan tingkat kepentingan yang semakin tinggi, dan sebaliknya. Berdasarkan Tabel 5, prioritas pertama adalah himpunan pairing terpilih nomor 13 dengan nilai 0,5225. Prioritas kedua adalah himpunan pairing terpilih nomor 19 dengan nilai 0,5221. Prioritas ketiga adalah himpunan pairing terpilih nomor 20 dengan nilai 0,5125 , dan seterusnya.

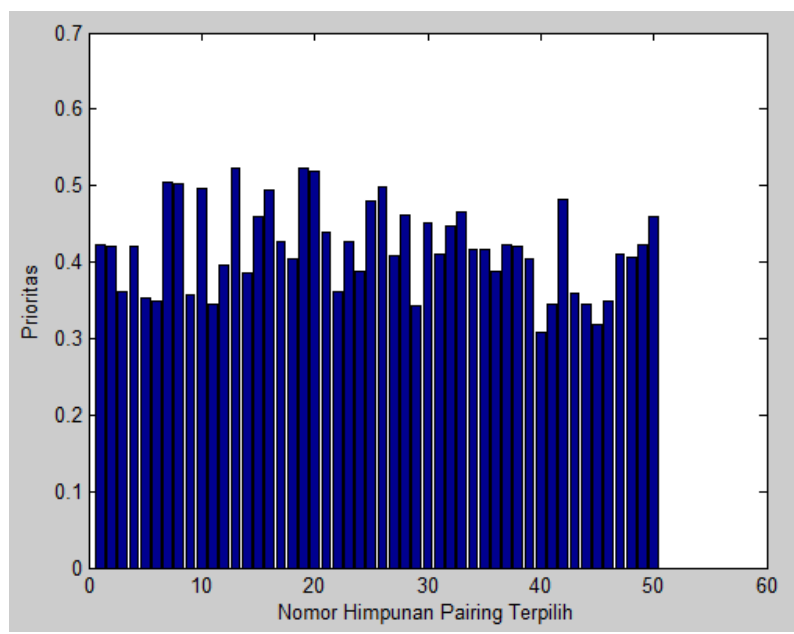


Gambar 5. Grafik Prioritas Pemilihan Himpunan Pairing Terpilih Menggunakan Fuzzy TOPSIS

Tabel 5. Peringkat Terbaik Pemilihan Himpunan Pairing Terpilih Menggunakan Fuzzy TOPSIS

\begin{tabular}{ccccccccc}
\hline $\begin{array}{c}\text { Pering } \\
\text { kat }\end{array}$ & $\begin{array}{c}\text { Nomor } \\
\text { Himpunan } \\
\text { Pairing } i\end{array}$ & Nilai $C C_{i}$ & $\begin{array}{c}\text { Jumlah } \\
\text { Dead } \\
\text { head }\end{array}$ & $\begin{array}{c}\text { Jumlah } \\
\text { Pairing } \\
\mathrm{A}^{2}\end{array}$ & $\begin{array}{c}\text { Jumlah } \\
\text { Pairing } \\
\mathrm{A}^{3}\end{array}$ & $\begin{array}{c}\text { Jumlah } \\
\text { Pairing } \\
\mathrm{A}^{4}\end{array}$ & $\begin{array}{c}\text { Jumlah } \\
\text { Pairing } \\
\mathrm{A}^{5}\end{array}$ & $\begin{array}{c}\text { Jumlah } \\
\text { Pairing } \\
\mathrm{A}^{6}\end{array}$ \\
\hline 1 & 13 & 0,5225 & 96 & 4 & 0 & 57 & 4 & 9 \\
2 & 19 & 0,5221 & 97 & 4 & 3 & 56 & 2 & 10 \\
3 & 20 & 0,5185 & 103 & 5 & 4 & 55 & 3 & 10 \\
4 & 7 & 0,5054 & 90 & 7 & 2 & 48 & 4 & 12 \\
5 & 8 & 0,5022 & 83 & 1 & 3 & 53 & 4 & 9 \\
6 & 26 & 0,4978 & 92 & 2 & 2 & 52 & 2 & 13 \\
7 & 10 & 0,4966 & 102 & 3 & 3 & 58 & 3 & 9 \\
8 & 16 & 0,4946 & 98 & 3 & 2 & 52 & 4 & 12 \\
9 & 42 & 0,4816 & 91 & 6 & 1 & 47 & 6 & 12 \\
10 & 25 & 0,4792 & 97 & 6 & 5 & 51 & 4 & 10 \\
\hline
\end{tabular}

Berdasarkan hasil menggunakan AHP dan Fuzzy TOPSIS, terdapat 6 himpunan pairing terpilih yang beririsan yaitu :

1. Himpunan pairing terpilih nomor 8 dengan peringkat pertama menggunakan AHP, peringkat kelima menggunakan Fuzzy TOPSIS.

2. Himpunan pairing terpilih nomor 26 dengan peringkat kedua menggunakan AHP, peringkat keenam menggunakan Fuzzy TOPSIS.

3. Himpunan pairing terpilih nomor 13 dengan peringkat ketiga menggunakan AHP, peringkat pertama menggunakan Fuzzy TOPSIS.

4. Himpunan pairing terpilih nomor 42 dengan peringkat keempat menggunakan AHP, peringkat kesembilan menggunakan Fuzzy TOPSIS.

5. Himpunan pairing terpilih nomor 7 dengan peringkat kelima menggunakan AHP, peringkat keempat menggunakan Fuzzy TOPSIS.

6. Himpunan pairing terpilih nomor 19 dengan peringkat kesepuluh menggunakan AHP, peringkat kedua menggunakan Fuzzy TOPSIS.

Berdasarkan hasil perhitungan, metode AHP dan Fuzzy TOPSIS dapat memilih dan memberi peringkat prioritas pada pemilihan himpunan pairing terpilih.

\section{Kesimpulan dan Saran}

AHP dan Fuzzy TOPSIS dapat digunakan dalam menyelesaikan pengambilan keputusan dengan banyak kriteria. Sebelum menggunakan AHP atau Fuzzy TOPSIS, akan dibentuk kumpulan dari himpunan pairing terpilih menggunakan greedy algorithm. Setelah kumpulan himpunan pairing terpilih terbentuk, maka dibentuk goal dan kriteria. Goal adalah memilih himpunan pairing terpilih dari beberapa alternative. Pada setiap himpunan pairing yang terpilih, terdapat beberapa kriteria seperti jumlah deadhead, jumlah pairing $\mathrm{A}^{2}$, jumlah pairing $\mathrm{A}^{3}$, jumlah pairing $\mathrm{A}^{4}$, jumlah pairing $\mathrm{A}^{5}$, dan jumlah pairing $\mathrm{A}^{6}$. Berdasarkan hasil perhitungan, metode AHP dan Fuzzy TOPSIS dapat memilih dan memberi peringkat prioritas pada pemilihan himpunan pairing terpilih. 
Kekurangan pada penelitian ini adalah jumlah himpunan pairing terpilih yang digunakan pada percobaan masih relative kecil, sehingga dapat dikembangkan pada jumlah himpunan pairing terpilih yang besar sehingga pemberian peringkat pada metode AHP maupun Fuzzy TOPSIS dapat lebih optimal.

\section{Daftar Pustaka}

[1] R. D. P. Wibisono, "PENGARUH KUALITAS PELAYANAN, FASILITAS DAN KEPERCAYAAN MEREK TERHADAP LOYALITAS KONSUMEN (Studi Kasus pada Rumah Sakit Pelni Petamburan - Jakarta)," UNIVERSITAS ISLAM NEGERI SYARIF HIDAYATULLAH, 2016.

[2] E. Acar et al., "Development of Stitched, Braided and Woven Composite Structures in the ACT Program and at Langley Research Center (1985 to 1997)," J. Aircr., 2011.

[3] M. Rahardjo, "STUDI KASUS DALAM PENELITIAN KUALITATIF: KONSEP DAN PROSEDURNYA,” J. Pers. Soc. Psychol., 2017.

[4] A. Rahma Putri, "Perancangan Alat Penyiram Tanaman Otomatis pada Miniatur Greenhouse Berbasis IOT," pp. 155-159, 2019.

[5] C. Li, M. Negnevitsky, and X. Wang, "Prospective Assessment of Methanol Vehicles in China Using FANP-SWOT Analysis,” Transp. Policy, vol. 96, pp. 60-75, 2020.

[6] S. Barak and S. Javanmard, "Outsourcing Modelling Using a Novel Interval-Valued Fuzzy Quantitative Strategic Planning Matrix (QSPM) and Multiple Criteria Decision-Making (MCDMs)," Int. J. Prod. Econ., vol. 222, p. 107494, 2020.

[7] I. A. Risqiyah and I. Santoso, "RISIKO RANTAI PASOK AGROINDUSTRI SALAK MENGGUNAKAN FUZZY FMEA,” J. Manaj. dan Agribisnis, 2017.

[8] R. A. Sari, R. Yuniarti, and F. R. N. Safitri, "Evaluasi Kinerja Perusahaan Berdasarkan Perspektif Organisasi, Proses, dan Staf Berbasis AHP dan OMAX," J. Tek. Ind., vol. 19, no. 1, pp. 49-57, 2018.

[9] M. Yusuf, "STRATEGI PROSES TRANSISI DARI METODE SIX SIGMA KE DFSS ( DESIGN FOR SIX SIGMA ) MENGGUNAKAN APLIKASI AHP ( ANALYTICAL HIERARCHY PROCESS ),” Tek. Ind., no. June 2017, 2018.

[10] M. B. Bouraima, Y. Qiu, B. Yusupov, and C. M. Ndjegwes, "A Study on the Development Strategy of the Railway Transportation System in the West African Economic and Monetary Union (WAEMU) Based on the SWOT/AHP Technique," Sci. African, vol. 8, pp. 1-11, 2020.

[11] H. Retnowati, A. Sukmawati, and T. W. Nurani, "Strategi Peningkatan Kinerja Nelayan dalam Rantai Pasok Ikan Layur melalui Pengembangan Modal Insani di Pelabuhanratu," MANAJEMEN IKM: Jurnal Manajemen Pengembangan Industri Kecil Menengah, vol. 9, no. 2. pp. 140-149, 2014.

[12] F. J. Cabrerizo, M. A. Martínez, M. Herrera, and E. Herrera-Viedma, "Consensus in a fuzzy environment: A bibliometric study," Procedia Comput. Sci., vol. 55, no. Itqm, pp. 660-667, 2015. 
[13] H. Hosseini Nasab and A. S. Milani, "An Improvement of Quantitative Strategic Planning Matrix Using Multiple Criteria Decision Making and Fuzzy Numbers," Appl. Soft Comput. J., vol. 12, no. 8, pp. 2246-2253, 2012.

[14] H. Hosseini Nasab and A. S. Milani, "An Improvement of Quantitative Strategic Planning Matrix Using Multiple Criteria Decision Making and Fuzzy Numbers," Appl. Soft Comput., vol. 12, no. 8, pp. 2246-2253, Aug. 2012.

[15] M. Basjir, H. Supriyanto, and M. S. 3 Magister, "Pengembangan Model Penentuan Prioritas Perbaikan Terhadap Mode Kegagalan Komponen Dengan Metodologi FMEA, Fuzzy dan Topsis Yang Terintegrasi," Magister Tek. Ind. - Jur. Tek. Ind., vol. Prosiding, 2011.

[16] A. I. Nurani, A. T. Pramudyaningrum, S. R. Fadhila, S. Sangadji, and W. Hartono, "Analytical Hierarchy Process (AHP), Fuzzy AHP, and TOPSIS for Determining Bridge Maintenance Priority Scale in Banjarsari, Surakarta," Int. J. Sci. Appl. Sci. Conf. Ser., vol. 2, no. 1, p. 60, 2017.

[17] E. T. Tosida, H. Thaheer, and S. Maryana, "Strategi Peningkatan Daya Saing Melalui Framework Rantai Nilai Untuk Kompetensi Usaha Jasa Telematika Indonesia," J. Penelit. Pos dan Inform., vol. 5, no. 1, p. 1, 2017.

[18] M. Tavassoli, R. F. Saen, and D. M. Zanjirani, "Assessing sustainability of suppliers: A novel stochastic-fuzzy DEA model," Sustain. Prod. Consum., vol. 21, pp. 78-91, 2020.

[19] P. K. Marhavilas, M. Filippidis, G. K. Koulinas, and D. E. Koulouriotis, "A HAZOP with MCDM based risk-assessment approach: Focusing on the deviations with economic/health/environmental impacts in a process industry," Sustain., vol. 12, no. 3, 2020.

[20] A. A. Longaray, J. De Deus Rodrigues Gois, and P. R. Da Silva Munhoz, "Proposal for using AHP method to evaluate the quality of services provided by outsourced companies," Procedia Comput. Sci., vol. 55, no. Itqm, pp. 715-724, 2015.

[21] S. Kumar and A. Garnaik, "A Case Study in Chair by Applying Quality Function Deployment \& Analytic Hierarchy Process,” no. 2006, pp. 1001-1007, 2016.

[22] E. Nurmianto and A. H. Nasution, "PERUMUSAN STRATEGI KEMITRAAN MENGGUNAKAN METODE AHP DAN SWOT ( Studi Kasus pada Kemitraan PT . INKA dengan Industri Kecil Menengah di Wilayah Karesidenan Madiun )," Fak. Ekon., vol. 1, pp. 47-60, 2018.

[23] S. Supriyadi, K. Mawardi, and A. Nalhadi, "Minimasi Biaya Dalam Penentuan Rute Distribusi Produk Minuman Menggunakan Metode Savings Matrix," Semin. Nas. Inst. Supply Chain dan Logistik Indones. Univ. Hasanuddin Makasar, no. September, pp. 1-8, 2017.

[24] D. P. Alam Syah, "Metode Analytical Hierarchy Process: Sistem Rekomender Database Software," J. Inform., vol. 1, no. 2, pp. 59-73, 2014.

[25] A. A. Mahmudi, B. Surarso, and A. Subagio, "Kombinasi Balanced Scorecard dan Objective Matrix Untuk Penilaian Kinerja Perguruan Tinggi,” J. Sist. Inf. Bisnis, vol. 4, no. 1, pp. 1-10, 2014. 